\title{
UMA SINFONIA DE AUTORIDADES: NOTAS SOBRE A EXEGESE DOS ANTIGOS - PLOTINO, ENÉADA $V, 1$ [10], 8-9 ${ }^{1}$
}

Loraine Oliveira* lorainebpi@hotmail.com

RESUMO Este estudo apresenta a exegese dos Antigos em V,1 [10], 8-9, mostrando que Plotino estabelece um acordo entre as autoridades mencionadas: todos os Antigos por ele aludidos já conheciam, ainda que de modo implícito e inexato, a doutrina das três naturezas. De modo geral, a imprecisão dos seus predecessores consistia em confundir o Um e o Intelecto. Seguindo passo a passo o argumento de Plotino, tenta-se compreender, especialmente, a função de três dentre os filósofos citados. Primeiro, Platão, considerado o testemunho mais exato das antigas doutrinas. Depois, Aristóteles, contra quem Plotino polemiza, mas que parece servir de modelo para a exegese de alguns dentre os filósofos anteriores a Platão. Finalmente, Ferécides, que encerra uma alusão à doutrina pitagórica e, talvez, também, à tradição mítica.

Palavras-Chave Plotino; Exegese; Antigos; Três Naturezas; Um; Intelecto.

ABSTRACT This study presents the exegesis of the Ancients in V,1 [10], 8-9, showing that Plotinus establishes an agreement between the mentioned

1 Este trabalho foi realizado com o apoio do Conselho Nacional de Desenvolvimento Científico e Tecnológico - CNPq. São de responsabilidade da autora todas as traduções do texto de Plotino, além daquelas às quais não segue referência ao tradutor na citação da obra entre parênteses. Para as transliterações do grego, seguem-se, em geral, as normas estabelecidas pela SBEC (Sociedade Brasileira de Estudos Clássicos).

* Doutoranda em História da Filosofia, Programa de Pós-Graduação em Filosofia, FAFICH, UFMG, Belo Horizonte, Brasil. Artigo recebido em junho e aprovado em outubro de 2007.

KRITERION, Belo Horizonte, no 116, Dez/2007, p. 467-479. 
authorities; all the Ancients alluded by him already knew, though implicitly and inaccurately, the doctrine of the three natures. In general, the inaccuracy of his predecessors consisted in mistaking the One for the Intellect. Following Plotinus's argument step by step, we especially try to understand the role of three philosophers among the ones mentioned. First, Plato, who is considered the most accurate certification of the former doctrines. Then, Aristotle, against whom Plotinus polemicizes, although he seems to serve as a model for the exegesis of some philosophers before Plato. Finally, Pherekydes, who alludes to the Pythagorean doctrine and perhaps to the mythical tradition as well.

Keywords Plotinus; Exegesis; The Ancient; Three Natures; One; Intellect.

É consabido que a exegese é uma prática comum no conjunto das Enéadas, podendo ser considerada constituinte do método filosófico de Plotino. De fato, os tratados de Plotino contêm inúmeras alusões aos seus predecessores, normalmente sem nomeá-los. Tais alusões são, muitas vezes, esquemáticas e imprecisas, e mesmo emaranhadas umas nas outras, tornando difícil identificar os autores em questão. Porém, há um texto singular no conjunto da obra de Plotino, no qual ele se declara exegeta de antigas doutrinas, trazendo à luz os nomes de Parmênides, Anaxágoras, Heráclito, Empédocles, Aristóteles, Pitágoras e seus discípulos e, enfim, Ferécides, além de Platão. Trata-se dos capítulos 8 e 9 do tratado V, 1 [10], intitulado Sobre as três hipóstases que são princípios. $^{2}$

Esses filósofos Antigos são mencionados com o intuito de comprovar a doutrina que é exposta no tratado, que Plotino tenta mostrar que é muito antiga e que foi testemunhada por Platão. Tal declaração propõe algumas questões interessantes. Primeiro, quais são essas antigas doutrinas? Segundo, se Platão é considerado testemunha de tais doutrinas, qual o uso feito por Plotino do testemunho platônico nessa exegese dos Antigos? Ainda há de se observar que Plotino menciona Aristóteles, de quem Platão nada pôde testemunhar.

2 Há um outro texto nas Enéadas em que Plotino, também, nomeia seus predecessores, IV, 8 [6] 1, 11-50. Nesse caso, ele menciona Heráclito, Empédocles, Pitágoras e seus sucessores. Sobre esse trecho em relação a V, 1 [10], 8-9, ver: O'MEARA, D. Plotin "historien" de la philosophie. In: BRANCACCI, A. (Ed.). Philosophy and doxography in the imperial age. Firenze: Leo S. Olschki editore, 2005. p. 103-112. 
Com efeito, os Antigos são divididos em dois grupos: anterior (próteron) ${ }^{3} \mathrm{e}$ posterior (hysteron) ${ }^{4}$ a Platão.

O presente estudo tem por escopo apresentar a exegese tal como praticada em V, 1 [10], 8-9, mostrando que se trata de uma sinfonia de autoridades, a qual serve como fundamento para a doutrina de Plotino, sendo Platão considerado a autoridade máxima, através de quem todas as demais são postas em acordo.

\section{Platão, testemunho das antigas doutrinas}

Os dois capítulos sobre os quais versa esse estudo encontram-se quase no final do tratado $\mathrm{V}, 1$. Eis porque é interessante observar, sumariamente, a estrutura do tratado. O ponto de partida de V, 1 é a alma que esqueceu sua origem e que, portanto, deve ser conduzida a lembrar da sua raça (génos) e valor (axía). ${ }^{5}$ Assim, o tratado desenvolve-se percorrendo o que pode ser chamado de genealogia metafísica da Alma: os capítulos 2 e 3 discorrem acerca da natureza e da condição da Alma, mostrando que, tão logo seja produzida pelo Intelecto, sua função é dar vida ao mundo sensível. Os capítulos 4 a 6 versam sobre o Intelecto e o mundo inteligível, sua estrutura e o modo como é gerado pelo Um. No final do sexto capítulo, Plotino retoma o tema do engendramento da Alma pelo Intelecto e explica que toda realidade engendrada precisa do princípio que a engendrou e deseja unir-se a tal princípio. O sétimo capítulo mostra que o Intelecto é imagem do Um e que todas as coisas recebem, em última instância, sua forma e determinação do Um. Não obstante, o Intelecto contém todas as realidades inteligíveis nele, tal como Cronos, que devora seus filhos logo após nascerem. Saturado, ele engendra Zeus, do mesmo modo que o Intelecto perfeito engendra a Alma. Nesse capítulo, Plotino tem por encerrada a exposição acerca das "realidades divinas". ${ }^{6}$ Isto posto, Plotino trata de mostrar que essa teoria das três naturezas, ${ }^{7}$ o Um, o Intelecto e a Alma, encontra-se nos seus predecessores, notadamente, em Platão.

Isto posto, nas primeiras linhas do capítulo 8, Plotino alude à Carta II, à Carta VI, ao Fédon, ao Timeu e à República, tentando confirmar a doutrina que foi apresentada até este ponto: 
Eis a razão porque Platão diz haver três realidades: todas as coisas em torno ao rei de todas as coisas - chama-as primeiras -, o segundo em torno às segundas, e o terceiro em torno às terceiras. ${ }^{8}$ Diz também que há um pai da causa, ${ }^{9}$ chamando causa $o$ Intelecto, ${ }^{10}$ pois para ele o Intelecto é o demiurgo. Ele afirma que $<_{0}$ demiurgo $>$ cria a Alma naquela cratera ${ }^{11}$. E como a causa é o Intelecto, por pai entende o Bem, ou seja, o que está além do Intelecto e além da essência ${ }^{12}(\mathrm{~V}, 1$ [10] 8, 1-10).

Essa passagem exemplifica uma prática assaz freqüente no que tange à exegese dos textos de Platão. Plotino retira palavras, frases, ou parte de frases, de diferentes obras platônicas e aglutina-as, conferindo ao conjunto um sentido exógeno ao do contexto em que essas passagens figuram originalmente. Com efeito, Plotino parece fazer as seguintes correspondências: ao Um correspondem, em Platão, o Bem (República), o rei de todas as coisas (Carta II) e o pai da causa (Carta VI). Ao Intelecto corresponde o demiurgo (Timeu) e a causa (Fédon e Filebo). À Alma, a alma do mundo (Timeu).

Desse modo, Plotino afirma que sua filosofia não é nova nem de hoje, pois já estava presente em antigos discursos, de forma implícita (mè anapeptaménos). Assim, ele declara-se exegeta (exegetás) das antigas doutrinas. Para levar a cabo a tarefa de exegeta, apóia-se nos escritos de Platão, que testemunham (martyríois) a antiguidade das referidas doutrinas. ${ }^{13}$

Observe que essa é a única ocorrência do termo exegetás nas Enéadas. De fato, essa palavra era um termo técnico do vocabulário dos alegoristas, designando a tarefa de decifrar um tipo de discurso que não é explícito, quer dizer, que é enigmático, misterioso. ${ }^{14}$ Ora, é consabido que a filosofia passa a ter a forma de comentário de texto a partir do século I a.C. Por conseguinte, pode-se dizer que, antes de haver sido adotada pelos filósofos, a exegese foi praticada pelos alegoristas de Homero, pelos retores e pelos gramáticos. Essas tradições foram úteis aos exegetas filósofos. De tal modo que as regras da

8 "Em torno ao rei de todas as coisas encontram-se todas as coisas; é em vista dele que tudo existe e é ele que é a causa de absolutamente tudo o que é belo. Em torno ao segundo, encontram-se as coisas de segundo nível; e em torno ao terceiro, as coisas de terceiro nível" (Carta II, 312 e 1-4).

9 "(...) e que é o soberano pai do chefe e da causa" (Carta Vl, 323 d 4).

10 "(...) afirmava-se que o intelecto é a causa ordenadora e universal de todas as coisas" (Fédon, 97 c 2. Trad. modificada de M. T. S. de Azevedo). Ver, também, Filebo 30 c, onde Platão identifica a causa e o Intelecto.

11 "Havendo assim falado <0 demiurgo>, retomou a cratera em que antes compusera por uma mistura a alma do mundo" (Timeu, 41 d 4-5. Trad. modificada de C. A. Nunes). Ver, também: Timeu, 34 b-35 b.

12 “(... ) apesar de o bem não ser uma essência, mas estar acima e para além da essência, pela sua dignidade e poder" (República, 509 b 9. Trad. M. H. da Rocha Pereira).

13 "Estes discursos não são novos e não datam de hoje. Eles foram proferidos faz muito tempo, mas de modo não explícito. Hoje nossos discursos são os de exegetas destas antigas doutrinas cuja antiguidade nos é testemunhada pelos textos de Platão" (V, 1 [10] 8, 10-14).

14 Cf. PEPIN, J. Mythe et allégorie. Les origines grecques et les contéstations judéo-chrétiennes. Nouvelle édition révue et augmenté. Paris: Etudes Augustiniennes, 1976. p. 497. 
exegese, tendo sido codificadas pela retórica, encontram-se, de certo modo, na interpretação dos textos filosóficos. ${ }^{15}$ Entrementes, os filósofos exegetas do século III d.C., como Plotino, consideram que a verdade se encontra nos textos do fundador da tradição a qual seguem - no caso de Plotino, trata-se da tradição platônica. Por conseguinte, "a arte do exegeta consiste em saber conciliar a letra do texto com o que o intérprete considera como a verdade, contida e oculta no texto". ${ }^{16}$ Todavia, Plotino não oblitera a tradição filosófica Antiga, nem mesmo a mítica. Embora não seja possível, neste estudo, examinar a exegese dos mitos, pode-se assinalar que, além da genealogia de Urano, Cronos e Zeus, encontram-se, nas Enéadas, interpretações alegóricas de não menos de trinta figuras da mitologia de Homero e Hesíodo. ${ }^{17}$ Com relação aos filósofos Antigos, no tratado V, 1 [10], os escritos de Platão assumem um papel muito particular, o de testemunhas na exegese das doutrinas não explicitadas dos Antigos. ${ }^{18}$ Todavia, para Plotino, não se trata de um qualquer testemunho, mas, sim, do mais exato, como se pode verificar a seguir.

\section{Antes de Platão: Parmênides, Anaxágoras, Heráclito e Empédo- cles}

Plotino diz que, antes de Platão, Parmênides aproximou-se da mesma doutrina das três naturezas, ${ }^{19}$ pois ele identificou o ser e o pensamento, ${ }^{20}$ não situando o ser entre as coisas sensíveis. Ademais, ele disse que o ser é imutável, logo permanece imóvel, ${ }^{21}$ assemelhando-se à esfera. A esfera, segundo Plotino, inclui todas as coisas, possuindo, no seu interior, o pensamento. ${ }^{22} \mathrm{Em}$ suma, Plotino considera que Parmênides uniu o ser e o pensamento, todavia

15 "A retórica havia codificado as regras da exegese dos textos, em relação à interpretação do direito. A propósito da controvérsia concernente ao direito, distinguiam-se quatro questões: é preciso deter-se no texto ou na intenção daquele que o escreveu? Qual texto reter quando dois textos são contraditórios? Pode-se, raciocinando sobre dois textos, obter uma conclusão que não está no texto? Tais questões encontram-se, evidentemente, na interpretação de textos filosóficos" (HADOT, P. Théologie, exégèse, révélation, écriture, dans la philosophie grecque. In: TARDIEU, M. (Éd.). Les règles de l'interprétation. Paris: Cerf, 1987. p. 19).

16 HADOT, ibidem, p. 19.

17 Vejam apenas alguns exemplos de mitos interpretados por Plotino: o nascimento de Eros e Afrodite, no tratado III, 5 [50]; Hércules, no tratado IV, 3 [27] e, também, em I, 1 [53], 12, 32; Ulisses e Narciso, em I, 6 [1] 8, 15-21; Prometeu e Epimeteu, em IV, 3 [27], 14, 12; Deméter, em IV, 4 [28].

18 Como observa O'MEARA, op. cit., p. 107.

19 Plotino menciona Parmênides em V, 1 [10] 8, 14-27. No corpo do texto, vai sendo seguida a argumentação plotiniana dessa passagem, podendo-se acompanhar, nas notas, as passagens às quais Plotino parece aludir, tanto de Parmênides, como do Parmênides de Platão.

20 "Pois a mesma coisa são o ser e o pensar" (PARMÊNIDES, DK 28 B 3).

21 “(...) ele [o ser] é imóvel (...) sem começo e sem fim (...). Idêntico a si mesmo, em si mesmo ele repousa. Ele está em si mesmo imóvel no seu lugar" (PARMÊNIDES, DK 28 B 8, 25-30).

22 Para a metáfora da esfera em Parmênides, ver: DK 28 B 8, 43. 
errou ao empregar a expressão "um" para nomear o ser. Ao fazer isso, ele atribuiu multiplicidade ao Um. Então, Plotino evoca o diálogo Parmênides de Platão, em que este apresenta a unidade de cada nível de realidade, de modo mais exato (akribésteron) que o próprio Parmênides: o primeiro Um é, propriamente, um; ${ }^{23}$ o segundo um é um - múltiplo; ${ }^{24}$ e o terceiro um é um e múltiplo. ${ }^{25}$ Por conseguinte, o diálogo platônico é mencionado a fim de corrigir uma inexatidão de Parmênides.

A seguir, Plotino cita mais três filósofos anteriores a Platão. "Anaxágoras, ao falar que o Intelecto é puro e sem mistura, estabelece, também, que o primeiro é simples e o Um, separado. Mas, dada sua antiguidade, negligenciou a precisão." ${ }^{26} \mathrm{Ou}$ seja, sua imprecisão consiste em identificar o Intelecto e o Um. Por sua vez, Heráclito "sabe que o Um é eterno e inteligível, porque os corpos devêm eternamente e fluem". ${ }^{27}$ Empédocles considera que a discórdia dissocia e a amizade é o Um, o qual concebe como incorpóreo. ${ }^{28}$ A confirmação de uma doutrina, através da referência aos antigos, é praticada, também, por Aristóteles, como observa O'Meara, que, assim como Atkinson, também percebe a proximidade, sob certos aspectos, entre este histórico, apresentado por Plotino, da teoria das três naturezas e a doxografia dos predecessores, concernente aos primeiros princípios, no início da Metafísica. ${ }^{29}$ Em breves linhas, Aristóteles observa que, para Anaxágoras, tudo estava misturado, exceto o Intelecto, puro e sem mistura; ele, também, considera que falta exatidão a Anaxágoras. ${ }^{30}$ Quanto a Empédocles, diz que, para ele, a amizade é a causa dos bens e o próprio bem, enquanto a discórdia é a causa dos males e o próprio mal. ${ }^{31}$ Finalmente, Aristóteles afirma que, segundo as doutrinas heraclitianas,

23 Alusão à primeira hipótese do Parmênides: o Um não é um todo nem tem partes se é um (cf. PLATÃo. Parmênides, 137 c-142 a).

24 Refere-se à segunda hipótese, na qual o um é múltiplas coisas (PLATÃo. Parmênides, 144 e-151 e). A segunda hipótese prossegue tentando mostrar que o um - múltiplo - está no tempo, mas, nisso, Plotino não segue Platão, motivo pelo qual se pode considerar que se trata de uma alusão parcial à segunda hipótese.

25 Trata-se, agora, da terceira hipótese, na qual o um é um e múltiplas coisas (cf. PLATÃo. Parmênides, 155 e-157 b).

26 V, 1 [10] 9, 1-3. Para Anaxágoras, o Intelecto parece ser o princípio racional de todas as coisas, não sendo misturado a nenhuma coisa e sendo a mais pura dentre as coisas (cf. DK 59 B 12).

27 V, 1 [10] 9, 3-5. Pode ser uma alusão a DK $22 \mathrm{~A} 1$, onde Heráclito diz que todas as coisas fluem à maneira de um rio.

28 Cf. V, 1 [10] 9, 5-7. Provavelmente, refere-se a DK 31 B 17 e a 31 B 20, nos quais Empédocles diz que a amizade faz as coisas adquirirem uma ordem única.

29 Cf. O'MEARA, op. cit., p. 110. Ver, também, ATKINSON, M. Plotinus. Ennead V. 1. Oxford: Oxford University Press, 1983, p. 199, para quem a menção e a interpretação dos pré-socráticos é feita de acordo com as interpretações de Aristóteles e a tradição doxográfica da Metafísica.

30 Cf. ARISTÓTELES. Metafisica, 989 b 16-17 e 19-20.

31 Cf. ARISTÓTELES. Metafisica, 985 a 5-10. 
todas as coisas estão em fluxo contínuo. ${ }^{32}$ Assim, de Aristóteles, Plotino parece haver tirado não somente informações acerca dos predecessores, mas, também, critérios de avaliação, tais como a clareza e a precisão, e, finalmente, a função de confirmação de uma doutrina através das opiniões anteriores. ${ }^{33}$

\section{Depois de Platão: Aristóteles}

Aristóteles, entretanto, é objeto de uma extensa crítica, que ocupa quase todo o nono capítulo do tratado V, 1 [10]. Plotino observa, inicialmente, que, para o Estagirita, o primeiro é separado e inteligível, mas, por outro lado, o primeiro pensa a si próprio, logo, deixa de ser primeiro. ${ }^{34}$ Ora, uma vez que o primeiro pensa a si mesmo, ele multiplica-se, pois o ato de pensar supõe aquele que pensa e o que é pensado. Plotino prossegue, dizendo que Aristóteles multiplica os inteligíveis, fazendo-os tão numerosos quanto as esferas celestes, a fim de que cada inteligível mova uma esfera; sendo assim, "ele fala dos inteligíveis de um modo diferente de Platão, atendo-se a um argumento provável (eúlogon), que não tem a força da necessidade (anánke)". ${ }^{35}$ O que isso quer dizer? Nas Enéadas, parece que um argumento provável tem menos força que outro, necessário, pois o argumento necessário decorre de um encadeamento, não somente lógico, mas também ontológico, que lhe fornece a prova. ${ }^{36}$ Então, Plotino parece criticar, em Aristóteles, não somente o fato de ele haver falado de modo diferente de Platão, mas também o fato de que seu argumento não tem um fundamento ontológico.

Porém, segundo Jaeger, a crítica a Aristóteles, na passagem em questão, parece fundamentar-se em pontos da Metafísica de Teofrasto. ${ }^{37}$ Para compreender o paralelo entre Teofrasto e Plotino, é mister verificar, primeiramente, o que diz Aristóteles. Com efeito, há uma passagem, da Metafísica L, ${ }^{38}$ que

32 Cf. ARISTÓTELES. Metafisica, 987 a 33-34.

33 Cf. O'MEARA, op. cit., p. 111.

34 Cf. V, 1 [10] 9, 7-9. A crítica à teoria do primeiro que pensa a si mesmo, possivelmente, refere-se à Metafísica $1071 b$.

$35 \mathrm{~V}, 1$ [10] 9, 9-11.

36 Essa dupla de conceitos, provável e necessária, ocorre três vezes no corpus plotiniano. Uma, no tratado em estudo, e as outras duas, em VI, 5 [23] 8, 1-6 e V, 3 [49] 6, 40-42.

37 "Na Antiguidade tardia, quando se despendia muito esforço e uma grande perspicácia para interpretar a filosofia aristotélica, Plotino fez uma crítica decisiva dessa teoria, na qual ele desenvolvia as dúvidas suscitadas por Teofrasto" (J AEGER, W. Aristote. Fondements pour une histoire de son évolution. Paris: Éditions de l'Éclat, 1997. p. 361).

38 "Portanto, dado que seja esse o número das esferas, será provável, conseqüentemente, admitir que serão do mesmo número as substâncias e os princípios imóveis: e que isso seja necessário, deixamos a decisão aos que são especializados na matéria" (ARISTÓTELES. Metafísica, 1074 a 14-17. Tradução, ligeiramente modificada, de M. Perine). 
versa sobre as esferas, na qual Aristóteles faz referência, com a palavra eúlogon, aos raciocínios dos astrônomos, aos quais recorre para encontrar o número de translações dos astros, porquanto os filósofos não forneceram explicação clara a respeito. Assim, Aristóteles faz uso da probabilidade (eúlogon) porque não pode atingir a necessidade apodítica. Segundo Aristóteles, a astronomia é, dentre as ciências matemáticas, a mais próxima da filosofia, pois investiga uma substância que é sensível, mas eterna, ao passo que a geometria e a aritmética não têm nenhuma substância por objeto. ${ }^{39}$ Ora, para Teofrasto, "a questão do número das esferas exige uma discussão mais completa do seu fundamento, pois a explicação dos astrônomos não é suficiente". ${ }^{40}$ Assim, ao que tudo indica, tanto Plotino como Teofrasto criticam a falta de um fundamento ontológico para a questão.

Todavia, mesmo o que Aristóteles pôde avançar, baseado nos astrônomos, é contestável para Plotino. Segundo ele, o argumento do Estagirita não é, nem mesmo, provável, pois é mais provável que todas as esferas sejam postas em movimento por uma só coisa, o que é primeiro, uma vez que elas realizam uma ordem única. Mas admitindo, como fez Aristóteles, que há uma multiplicidade de inteligíveis, eles provêm de um só e primeiro princípio, ou de vários princípios inteligíveis? ${ }^{41}$ Aqui, novamente, Plotino parece ecoar Teofrasto, quando este interroga acerca da unidade ou da multiplicidade dos motores. ${ }^{42}$ Evidentemente, não é possível saber, com certeza, se Plotino leu Teofrasto, mas sabe-se que lia textos de peripatéticos, dos séculos II e III d.C., como atesta Porfírio. ${ }^{43}$ Sendo como for, Plotino deve ter conhecido os debates suscitados, na Antiguidade tardia, pelo livro L da Metafísica.

Dessarte, Plotino conclui a polêmica, investigando as possibilidades da questão que ele havia proposto, a saber, se há um ou mais princípios inteligíveis para Aristóteles. ${ }^{44}$ Plotino tenta mostrar, com efeito, que há apenas um princípio. Em suma, Plotino diz que, se as esferas constituem um conjunto unificado, devem voltar seus olhos em direção a um princípio único, o primeiro. Em seguida, ele estabelece uma analogia com as esferas que se encontram no sensível, onde uma contém a outra, para concluir que o primeiro

39 Cf. ARISTÓTELES. Metafísica, 1073 b 4-8.

40 TEOFRASTO. Metafísica, 2 a 22-23.

41 Cf. V, 1 [10] 9, $12-17$.

42 "Pois se o motor é um, é estranho todos não seguirem a mesma translação (...)" (TEOFRASTO. Metafísica, 5 a 17). "É Teofrasto que levanta essa objeção, que situa as questões de mecânica celeste no centro do seu fragmento de metafísica" (Cf. J AEGER, 359).

43 Porfírio testemunha que, nas aulas de Plotino, "liam-se os comentários (ypomnémata) de Severo, Crônio, Numênio, de Gaio ou de Ático, ou, sobre os peripatéticos, os de Aspásio, de Alexandre, de Adrasto e de outros que estavam à disposição" (PORFíRIO. Vida de Plotino, 14, 10-15).

44 Ver nota 38 supra. 
princípio "lá", ou seja, no inteligível, deve conter os inteligíveis. E isso é o mundo inteligível. Mas se, ao contrário, cada esfera possuísse um princípio, o movimento seria por acaso e não haveria harmonia no céu. Um outro ponto concerne à corporeidade dos princípios que provocam o movimento das esferas. Se os inteligíveis não têm corpo, eles não podem ser múltiplos, pois a multiplicidade provém da matéria que separa uma coisa da outra. ${ }^{45}$

\section{A menção a Ferécides}

Ao concluir a polêmica contra Aristóteles, Plotino aborda um último grupo de Antigos. São aqueles que se situam ao lado de Pitágoras, seus sucessores e de Ferécides. ${ }^{46}$ Mas, aqui, Plotino não expõe suas doutrinas. Ele apenas cita os nomes. A menção a Ferécides suscita diferentes interpretações, sendo suficiente mencionar ao menos duas, a de Alain Éon e a de Dominic O'Meara, distintas uma da outra. Em seu estudo sobre a exegese em Plotino, A. Éon ${ }^{47}$ atribui considerável importância à menção de Ferécides, pois, segundo ele, o nome de Ferécides permite delimitar, com rigor, a passagem, ligando claramente as doutrinas antigas examinadas, nos capítulos 8 e 9, aos mitos de genealogias divinas que o próprio Plotino havia exposto anteriormente no tratado. ${ }^{48}$ Éon está contrapondo-se à Bréhier, para quem os capítulos 8 e 9 deveriam ser isolados do conjunto do tratado e considerados um "excurso histórico e crítico sobre a doutrina das três hipóstases na filosofia grega clássica". ${ }^{49}$ Contudo, Éon parece estar correto em não isolar os capítulos 8 e 9, pois mesmo que estes apresentem um tipo singular de exegese, talvez corretamente chamada de histórica-crítica, ou ainda, doxográfica, deve-se observar que a exegese não é um complemento facultativo à exposição doutrinal, ${ }^{50}$ mas é constituinte do próprio método filosófico de Plotino, conforme menção no início deste estudo.

Assim, a posição de Éon tem o mérito de considerar o tratado como um todo, sem diminuir a importância dos dois capítulos doxográficos. Ademais, permite estabelecer um paralelo entre a exegese dos mitos e dos filósofos Antigos, haja vista que ambas se ligam através do nome de Ferécides. Por outro lado, Ferécides vem mencionado junto aos pitagóricos, o que abre margem para 
O’Meara fazer a seguinte afirmação: “É sem dúvida em relação com a idéia de uma tradição pitagórica que se deve compreender a frase "e de Ferécides". ${ }^{51}$ Ele aponta três fatos para atestar sua hipótese: 1. as lendas biográficas antigas, que faziam de Ferécides o mestre de Pitágoras; 2. Damáscio, em um contexto comparável, cita Ferécides como testemunho da doutrina dos três princípios, que seriam Zas, Ctônia e Cronos; 3. a aproximação entre Platão, Pitágoras e Ferécides também é feita por Porfírio. ${ }^{52}$ Atrelando o nome de Ferécides à tradição pitagórica, O’Meara não vê nela uma conexão com o mito genealógico do capítulo 7.

Com efeito, os antigos consideravam Ferécides mestre de Pitágoras ${ }^{53}$ e atribuíam à escola de Ferécides a definição da díade como audácia; essa definição figura, de certo modo, no início do tratado de Plotino. ${ }^{54}$ Segundo Aristóteles, Ferécides é um tipo de poeta que une à poesia raciocínios filosóficos, por não expressar tudo em linguagem mítica. Ferécides é, assim, incluído no rol dos antigos teólogos e poetas a quem Aristóteles alude para tentar elucidar a relação entre o bem e os princípios. Segundo ele, Ferécides considera o bem como sendo princípio gerador. ${ }^{55}$ Ademais, Ferécides é autor de uma Teogonia que conta o episódio da batalha de Cronos contra o monstro colubrino Ofioneu pela posse do céu. Vencedor, Cronos reina sobre os deuses. Narra, também, o reinado de Cronos e, depois, o de Zás. Não sendo possível saber se Plotino leu esta Teogonia, pode-se supor que ele tivesse conhecimento da sua existência. Porfírio menciona-a, o que faz crer que, na sua época, esta Teogonia, ou o que se conhecia a respeito dela, circulava por Roma. ${ }^{56}$ Pouco tempo antes de Plotino e Porfírio, à época de Diógenes Laércio, o livro de Ferécides encontrava-se conservado. ${ }^{57}$ Também se encontram muitas referências a ela na Biblioteca

51 O'MEARA, op. cit., p. 110. Mais adiante, p. 112, O'Meara observa que Numênio antecipou a concepção de uma tradição divina que remontava a Pitágoras, e à qual se ligam os autênticos platônicos. Essa tradição é explorada, especialmente, por J âmblico. Ele nota, ainda, que Plotino parece evocar Pitágoras como autoridade filosófica apenas nos tratados V, 1 [10] e IV, 8 [6].

52 Não é alvitre, deste estudo, estabelecer as comparações entre Damáscio e Plotino, bem como verificar a passagem de Porfírio, tal como O'Meara aponta. O leitor interessado pode consultar: O'MEARA, op. cit., p. 110.

53 Cf. DIÓgEnES LAÉRCIO, VIII, 2; DK 7 A 4; PORfíRIO. Vida de Pitágoras, 1, 2, 55; J ÂMBLICO. Vida de Pitágoras, 9, 11, 248 e 252. Diógenes Laércio, também, o inclui no rol dos Sete Sábios (cf. Proemium, 13).

54 “Para as almas, o princípio do seu mal é a audácia, e a geração, e a alteridade primeira, e o querer, enfim, ser de si mesmas" (V, 1 [10] 1, 4-5).

55 Cf. ARISTÓTELES. Metafísica, 1091 b 6-10. Note-se que Ferécides é tomado como paradigma dessa classe de poetas, posto ser ele o único nomeado textualmente.

56 “(...) quando Ferécides, o Sírio, fala de recessos e de covas e cavernas e portas e portões, e por intermédio deles se refere enigmaticamente ao nascimento e morte das almas" (PORFIRIO. Antro das ninfas, 31).

57 "Está conservado de <Ferécides> de Siro o livro que ele escreveu e que começa pelas palavras: 'Zas (Zeus), Cronos e Ctônia existiam sempre. Ctônia recebeu o nome Gê (Terra), pois Zas Ihe deu a terra à guisa de privilégio'"' (DL 1, 119). 
de Apolodoro. ${ }^{58}$ De tudo o que foi dito, pode-se tentar conciliar as posições de Éon e de O'Meara, considerando a menção a Ferécides uma referência à tradição pitagórica, o que não exclui a possibilidade de ligar, através do nome de Ferécides, as antigas doutrinas filosóficas aos mitos genealógicos antes aludidos. Quanto a saber o que há de comum entre a exegese dos mitos e a dos Antigos filósofos, sendo essa uma questão subsidiária, os limites impostos a este pequeno estudo não permitem investigá-la.

\section{Considerações finais}

Algumas considerações finais podem ser feitas acerca da exegese dos Antigos em V, 1 [10], 8-9. Em primeiro lugar, é mister observar que Plotino estabelece, de modo implícito, uma escala segundo a exatidão e outra segundo a antiguidade. Platão é tomado, como critério, para as duas escalas. Ele é mais exato que Parmênides, e o é, também, em relação a Aristóteles, que se engana ao não seguir os ensinamentos do antigo mestre. Contudo, Pitágoras, os pitagóricos e Ferécides não podem ser avaliados segundo o mesmo critério, uma vez que sua doutrina não foi exposta. Quanto à escala de antiguidade, também é Platão que serve como ponto de referência, estando os filósofos separados em dois grupos: anterior e posterior a Platão. Do grupo posterior a Platão faz parte, apenas, Aristóteles. Dentre os anteriores, são incluídos todos os demais, com exceção de Ferécides, Pitágoras e os pitagóricos. Estes não são, de fato, incluídos em nenhuma das duas escalas, possivelmente, porque os neoplatônicos entendiam que Pitágoras e os pitagóricos faziam parte da mesma tradição platônica.

Em segundo lugar, Plotino parece confirmar sua doutrina das três naturezas, estabelecendo um acordo entre ela e aquelas doutrinas dos Antigos, dos quais Platão é o testemunho mais exato. Todavia, em relação a Aristóteles, por um lado, Plotino parece fazer eco a alguns pontos da doxografia dos Antigos, no primeiro livro da Metafísica, mas por outro, Plotino tece uma crítica que ocupa boa parte do nono capítulo. Com efeito, a crítica a Aristóteles parece completar a exegese a Parmênides: tanto um como outro confundiram o Intelecto com o Um. Além disso, Aristóteles, também, multiplicou o inteligível. Assim, ao mostrar que o argumento do Estagirita não é sequer provável, pois do número de esferas não se

58 De fato, os três autores mais citados por Apolodoro são Hesíodo, quatorze vezes, Ferécides, treze vezes e Acusilau, dez vezes (cf. Apendice II - Le fonti della biblioteca. In: APOLLODORO. I miti greci. A cura di P. Scarpi traduzine di M. G. Ciani. Fondazione Lorenzo Valla/Arnaldo Mondadori editore, 1996. p. 687-688). Por conseguinte, Ferécides parece contar entre os maiores logógrafos e mitógrafos da Grécia. 
deduz a multiplicidade do princípio, Plotino reitera um aspecto da sua teoria das três naturezas: a multiplicidade provém da unidade. Donde se pode dizer que, por uma via polêmica, Plotino demonstra a validade da sua própria teoria.

Ademais, vale lembrar que a polêmica acerca de certas dificuldades, suscitadas pelo livro L da Metafísica, pode ter um caráter histórico, respondendo a questões levantadas pelos exegetas aristotélicos dos primeiros séculos, notadamente Teofrasto, conforme se tentou mostrar, sucintamente, neste estudo. Mas não somente Aristóteles parece ser criticado a partir de um filósofo menos antigo, Teofrasto. Parmênides o é através de Platão. Anaxágoras, Heráclito e Empédocles o são, possivelmente, a partir de Aristóteles. Pitágoras e os pitagóricos, cuja doutrina nem é mencionada, escapam à crítica, pois remontam a uma tradição divina, à qual, também, pertencem Platão e os platônicos, segundo Numênio, por exemplo. Vista sob esse ângulo, a exegese plotiniana repousa sobre camadas de interpretação.

Por fim, se a exegese dos Antigos fundamenta a doutrina filosófica das Enéadas, é mister observar que a filosofia de Plotino, definida por ele próprio como exegese de antigas doutrinas, fundamenta essa sinfonia de autoridades que caracteriza a exegese dos Antigos nos capítulos 8 e 9. Desse modo, estabelece-se como que um círculo de validação. Ora, a autoridade dos Antigos parece ser garantida pelo acordo entre essas doutrinas, entre si, entre elas e a de Plotino. Esse duplo acordo, por sua vez, é regido pela autoridade de Platão, que, de modo mais exato, soube expressar a verdade. Assim, o trabalho de exegeta, em V, 1 [10], 8-9, consiste em conciliar as antigas doutrinas com a verdade que Plotino considera estar contida nelas. Verdade esta que, de fato, consta de seus próprios pressupostos filosóficos, apresentados nos capítulos anteriores do tratado.

\section{Referências}

\section{1) Edições das Enéadas}

ATKINSON, M. Plotinus. Ennead V. 1. Oxford: Oxford University Press, 1983. HENRY, P. \& SCHWYZER, H.-R. Plotini Opera, Scriptorum classicorum Bibliotheca Oxoniensis, Oxford, Univ. Pr. (Editio minor), v. I-III, 1964-1982.

PLOTINO. Enéadas. PORFIRIO. Vida de Plotino. Introducciones, traducciones y notas de J. Igal. vols. I-III. Madrid: Gredos, 1992.

\section{2) Autores antigos}

APOLLODORO. I miti greci. A cura di P. Scarpi traduzine di M. G. Ciani. Fondazione Lorenzo Valla / Arnaldo Mondadori editore, 1996. 
ARISTOTE. La Metaphysique. Traduction et commentaire par J. Tricot. Paris: Vrin, 2003. ARISTÓTELES. Metafisica. V. II. Trad. G. Reale. Trad. brasileira M. Perine. São Paulo: Loyola, 2002.

DIELS, H., KRANTZ, W. Die Fragmente der Vorsokratiker: Griechisch und Deutsch (Wortindex von W. Kranz, Namen-und Stellenregister von H. Diels. Ergänzt von W. Kranz). Berlin: Weidmannsche Verlagsbuchandlung, 1960/1961, 3 v.

DIOGĖNE LAËRCE. Vie et doctrines des philosophes illustres. Trad. M.O. GouletCazé. Paris: LGF, Le livre de poche, 1999.

DIOGENES LAERTIUS. De vitis, dogmatis et apophthegmatis clarorum philosophorum libri decem. Edidit H. G. Huebnerus. Hildesheim: Georg Olms, 1981.

PITAGORA. Le opere e le testimonianze. Introduzione di W. Burkert. A cura di M. Giangiulio. 2 vol. Milano: Oscar Mondadori editore, 2000.

PLATÃO. Fédon. Introdução, versão do grego e notas M. T. S. de Azevedo. Brasília: Editora UNB; São Paulo: Imprensa Oficial, 2000.

PLATÃO. Parmênides. Trad. M. Iglésias e F. Rodrigues. Rio de Janeiro: PUC-Rio; São Paulo: Loyola, 2003.

PLATÃO. República. Trad. M. H. da Rocha. Lisboa: Fundação Calouste Gulbenkian, 2001.

PlATÃo. Timeu, Crítias, O Segundo Alcibíades, Hípias Menor. Trad. C. A. Nunes. Belém: EDUFPA, 2001.

PLATON. Lettres. Trad. L. Brisson. Paris: GF-Flammarion, 1987.

PLATON. Philèbe. Euvres complétes, tome IX - 2 partie. Trad. A. Diès. Paris: Les Belles Lettres, 1949.

PORFIRIO. La gruta de las ninfas: carta a Marcela. Trad. M. P. Lorente. Madrid: Ed. Clássicas, 1992.

THEOPHRASTE. Métaphysique. Trad. A. Laks et G. W. Most; avec la collab. de C. Larmore et E. Rudolph, et pour la trad. arabe de M. Crubellier. Paris: Les Belles Lettres, 1993.

\section{3) Comentários}

EON, A. La notion plotinienne d'exégèse. Révue internationale de philosophie, 92, p. 252-289, 1970.

HADOT, P. Théologie, exégèse, révélation, écriture, dans la philosophie grecque. In: TARDIEU, M. (Ed.). Les règles de l'interprétation. Paris: Cerf, 1987. p. 13-34.

JAEGER, W. Aristote: Fondements pour une histoire de son évolution. Paris: Éditions de l'Éclat, 1997.

O'MEARA, D. Plotin «historien» de la philosophie. In: BRANCACCI, A (Ed.). Philosophy and doxography in the imperial age. Firenze: Leo S. Olschki editore, 2005. p. 103-112.

PEPIN, J. Mythe et allégorie: Les origines grecques et les contéstations judéochrétiennes. Nouvelle édition révue et augmenté. Paris: Etudes augustiniennes, 1976. 